DAMNED LIES AND STATISTICS 


\title{
DAMNED LIES
}

\section{AND STATISTICS}

Untangling Numbers from the

Media, Politicians, and Activists

\author{
UPDATED EDITION
}

\section{Joel Best}

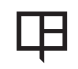

UNIVERSITY OF CALIFORNIA PRESS

Berkeley Los Angeles London 
University of California Press, one of the most distinguished university presses in the United States, enriches lives around the world by advancing scholarship in the humanities, social sciences, and natural sciences. Its activities are supported by the UC Press Foundation and by philanthropic contributions from individuals and institutions. For more information, visit www.ucpress.edu.

University of California Press

Berkeley and Los Angeles, California

University of California Press, Ltd.

London, England

(C) 2001, 2012 by

The Regents of the University of California

ISBN 978-0-520-27470-9

LIBRARY OF CONGRESS

CATALOGING-IN-PUBLICATION DATA

Best, Joel.

Damned lies and statistics : untangling numbers from the media, politicians, and activists / Joel Best.

p. $\mathrm{cm}$.

Includes bibliographical references and index. ISBN 978-0-520-21978-6 (cloth : alk. paper)

1. Sociology-Statistical methods. 2. Social problemsStatistical methods. 3. Social indicators. I. Title.

HM535.B47 2001

303.3'8-dc21 00-064910

Printed in the United States of America

$\begin{array}{lllllll}18 & 17 & 16 & 15 & 14 & 13 & 12\end{array}$

$\begin{array}{llllllllll}10 & 9 & 8 & 7 & 6 & 5 & 4 & 3 & 2 & 1\end{array}$

In keeping with a commitment to support environmentally responsible and sustainable printing practices, UC Press has printed this book on Rolland Enviro100, a 100\% post-consumer fiber paper that is FSC certified, deinked, processed chlorine-free, and manufactured with renewable biogas energy. It is acid-free and EcoLogo certified. 
For Kathe Lowney 